\title{
PENGARUH MENONTON PERTANDINGAN SEPAKBOLA DI TELEVISI TERHADAP PERILAKU SOSIAL ANAK DALAM BERMAIN SEPAKBOLA
}

\author{
Romi Cendra \\ Pendidikan Jasmani Kesehatan Dan Rekreasi, \\ Universitas Islam Riau \\ Email: romicendra@edu.uir.ac.id
}

\begin{abstract}
This study aimed to determine the effect of soccer matches on television to the social behavior of children in playing football. The research method used is ex post facto with causal-comparative research design that compares the heavy audience and light audiences. The sample in this research is SMAN 4 Garut Garut Regency West Java Province consists of 21 heavy viewers and 21 light viewers selected by purposive sampling. The results of data analysis can be concluded that the heavy audience of soccer games on television influence the social behavior of children in playing soccer with the significance value $0.019<0.05$ and seen from the average score score of social behavior group children heavy audience / often larger than the group of social behavior of children A light / sparse audience with a score of 146.52> 135.05. Thus there is a significant difference between the social behavior of the children with the heavy audience and the light audiences in playing football.
\end{abstract}

Keywords: Watching, social behavior. Soccer

\begin{abstract}
Abstrak: Penelitian ini bertujuan untuk mengetahui pengaruh pertandingan sepakbola di televisi terhadap perilaku sosial anak dalam bermain sepakbola. Metode penelitian yang digunakan adalah ex post facto dengan design penelitian causal-comparative yang membandingkan anak penonton berat dan penonton ringan. Sampel dalam penelitian ini adalah SMAN 4 Garut Kabupaten Garut Provinsi Jawa Barat terdiri dari 21 orang penonton berat dan 21 orang penonton ringan yang dipilih secara purposive sampling. Hasil analisis data dapat disimpulkan bahwa penonton berat pertandingan sepak bola di televisi berpengaruh terhadap perilaku sosial anak dalam bermain sepakbola dengan nilai signifikansinya $0.019<0.05$ dan dilihat dari nilai skor rata-rata kelompok perilaku sosial anak penonton berat/sering lebih besar dari kelompok perilaku sosial anak penonton ringan/jarang dengan skor $146.52>135.05$. Dengan demikian terlihat perbedaan yang signifikan antara perilaku sosial anak penonton berat dengan anak penonton ringan dalam bermain sepakbola.
\end{abstract}

Kata Kunci: menonton, perilaku social. Sepak bola

Perkembangan teknologi semakin hari semakin pesat, seiring dengan perkembangan zaman. Perkembangan teknologi informasi memberikan sumbangan yang sangat besar terhadap terjadinya globalisasi dunia. Teknologi informasi (IT) yang kini berkembang amat pesat, tidak bisa dipungkiri memberikan kontribusi yang signifikan terhadap seluruh proses globalisasi. Mulai dari wahana teknologi informasi yang paling sederhana berupa koran, majalah, perangkat radio, dan televisi, hingga internet dan telepon genggam dengan protokol aplikasi tanpa kabel (WAP), informasi mengalir dengan sangat cepat dan menyeruak kesadaran banyak orang (Jajat, 2010:5).

Secara perlahan-lahan namun efektif, media membentuk pandangan pemirsa terhadap bagaimana seorang melihat pribadinya dan bagaimana seseorang seharusnya berhubungan dengan dunia sehari-hari. Sedemikian besarnya pengaruh media terhadap masyarakat, sehingga bisa 
Romi Cendra, Pengaruh Menonton Pertandingan Sepakbola Di Televisi Terhadap Perilaku Sosial Anak Dalam

merubah perilaku seseorang seperti apa yang dilihatnya dimedia.

Salah satu media yang sangat besar pengaruhnya pada saat sekarang adalah televisi, hampir setiap rumah memiliki televisi bahkan sudah menjadi kebutuhan pokok bagi setiap rumah tangga. Acara televisi pada saat sekarang ini yang mengglobalisasi adalah acara olahraga. Z. Dziubinski, dkk. (2012) mengatakan: "Globalisasi dalam olahraga berarti bahwa, khalayak massa memiliki akses ke dalam siaran olahraga. Media massa memiliki olahraga yang menjadi fenomena global saat ini, hampir tak ada tempat di dunia karna olahraga, sebagaimana dibuktikan oleh fakta bahwa Komite Olimpiade Internasional adalah sebuah asosiasi lebih dari 200 komite nasional dan acara olahraga besar terlihat di televisi oleh miliaran pemirsa)".

Garrison, B (Pedersen, dkk. 2007:189) mengatakan dalam tulisannya "television's love affair with sports". Ini berarti antara televisi dan olahraga tidak bisa dipisahkan dalam arti kata saling membutuhkan, yang berarti bahwa olahraga tanpa media massa akan buntu dan media massa tanpa olahraga tidak laku.

Acara olahraga di televisi yang sangat mengglobal pada saat sekarang ini adalah pertandingan sepakbola, banyak orang yang tidak tahu dengan waktu dalam menonton pertandingan sepakbola di televisi, mulai dari sore, malam bahkan tahan begadang sampai dini hari demi menonton pertandingan sepakbola di televisi. Khususnya pelajar atau siswa yang sering menonton atau penonton berat pertandingan sepakbola di televisi sebagian mereka ada yang meniru gaya dari atlet yang dia sukai, seperti pakaiannya, potongan rambut, dan merek sepatu yang dipakai oleh atlet idolanya serta banyak pula diantara anak-anak atau siswa yang meniru cara atlet dalam bermain, baik itu sifat pemberani, sifat berkuasa, sifat inisiatif secara sosial, suka bergaul, sifat ramah, simpati, suka bersaing, sifat agresif, sifat kalem, dan suka pamer, kerjasama dalam tim, ketenangan dalam bermain, dan sportifitas bahkan ketika menonton pertandingan sepakbola terlihat emosionalnya meluap-luap, seolah-olah mereka lebih pintar dari pemain yang ditontonnya.

Kognisi akan terefleksi pada sikap terhadap sesuatu, yang berarti hasil asosiasi acara di media massa (khususnya televisi) yang tertanam dalam benak tiap-tiap orang akan mempengaruhi sikap ataupun perilakunya. Media mempunyai pengaruh yang sangat kuat dalam pembentukan kognisi seseorang. Media memberikan informasi dan pengetahuan yang pada akhirnya dapat membentuk persepsi. Penelitian yang dilakukan oleh Hakim, L (2006) tentang pengaruh media terhadap kognisi anak menunjukkan bahwa persepsi mempengaruhi sikap (attitude) dan perilaku seseorang, dan juga Dalam penelitian $Z$. Dziubinski, dkk. (2012) dikatakan "We are under the influence of a force which we cannot see or realize and which has a massive effect on our behavior and attitudes".

Berdasarkan teori Kultivasi Garbner, G (Kurniawan, 2013) menjelaskan bahwa televisi memiliki pengaruh yang besar atas sikap dan perilaku penontonnya. Pengaruh tersebut tidak muncul seketika melainkan bersifat kumulatif dan tidak langsung. Lebih jelasnya dapat dikemukakan bahwa pengaruh yang muncul pada diri penonton merupakan tahap lanjut setelah media itu terlebih dahulu mengubah bentuk keyakinankeyakinan tertentu pada diri mereka melalui berbagai acara yang ditayangkan.

Kritikus sosial Novak, M (Vivian, 2008:225) mengatakan televisi adalah pembentukan geografi jiwa, televisi membangun struktur ekspektasi jiwa secara bertahap, televisi melakukan itu persis seperti sekolah memberi pelajaran secara bertahap, selama bertahun-tahun, televisi mengajari pikiran yang belum matang dan mengajari mereka cara berpikir.

Kaitannya dengan respon tersebut, media massa televisi berperan aktif untuk dapat memberikan masukan pada kognisi individu siswa dan masyarakat melalui berbagai informasi dan pemberitaan yang disajikan. Stimulus yang diterima dari media massa akan direspon dan akhirnya dapat membentuk sikap dan perilaku seseorang (Jajat, 2010:10).

Mengenai terstimulusnya respon dari media massa. Bungin (2009:281) mengatakan bahwa teori stimulus-respon pada dasarnya merupakan suatu prinsip belajar yang sederhana, dimana efek merupakan reaksi terhadap stimulus tertentu. Dengan demikian seseorang dapat menjelaskan 
suatu kaitan erat antara pesan-pesan media dan reaksi audience.

Kaitannya dengan respon tersebut bahwa efek dari pertandingan sepak bola di televisi terhadap pembentukan perilaku sosial seseorang sangat berpengaruh terhadap apa yang dilihat dari objek yang dia sukai. Krech dkk (1963:106) menyatakan bahwa untuk melihat perilaku sosial seseorang itu dapat dilihat dari kecenderungan ciri-ciri respon interper-sonalnya, yang terdiri dari: (1) Kecenderungan peranan (Role Disposition); (2) Kecen-derungan perilaku dalam hubungan sosial (Sociometric Disposition); dan (3) Kecen-derungan perilaku Ekspresif (Expressive Disposition). Perilaku sosial juga identik dengan reaksi seseorang terhadap orang lain Baron \& Byrne (dalam Budiman, 2001:1). Perilaku itu ditunjukkan dengan perasaan, tindakan, sikap keyakinan, kenangan, atau rasa hormat terhadap orang lain. Perilaku sosial seseorang merupakan sifat relatif untuk menanggapi orang lain dengan cara-cara yang berbeda-beda.

Terkait dengan siswa, siswa merupakan elemen yang paling mudah terpengaruh oleh media massa televisi, oleh karena itu media massa televisi merupakan salah satu aspek yang bisa merubah perilaku sosial anak seperti perilaku peran, perilaku dalam hubungan sosial dan perilaku ekspresif dalam berinteraksi baik sesama teman maupun dalam perilaku mereka melakukan aktifitas olahraga.

\section{METODE}

Metode penelitian yang digunakan adalah ex post facto dengan design penelitian causal-comparative. Untuk memberikan gambaran mengenai alur pikir dalam penelitian ini penulis memberikan gambaran sebuah desain penelitian causal-comparative dari Fraenkel, dkk. Hal ini seperti yang diungkapkan oleh Fraenkel, dkk. (1993:321) bahwa :"The basic causal-comparative design involves selection two or more groups that differ on a particular variable of interest and comparing them on another variable or variables". Pendapat Fraenkel, dkk dapat di ambil kesimpulan bahwa desain kausalkomparatif melibatkan pemilihan dua atau lebih kelompok yang berbeda pada variabel tertentu yang menarik dan membandingkan mereka pada variabel lain. Menurut Sugiyono (2005:11) menjelaskan penelitian komparatif adalah suatu penelitian yang bersifat membandingkan.

Peneliti membandingkan anak-anak yang sering menonton atau penonton berat pertandingan sepakbola di televisi dengan anak-anak yang jarang menonton atau penonton ringan pertandingan sepakbola di televisi terhadap perilaku sosial anak dalam bermain sepakbola. Maka untuk memudahkan penelitian desain variabelnya seperti dibawah ini :

\section{Tabel 1. Desain Penelitian Causal} Comparative

\begin{tabular}{ccc}
\hline Group & $\begin{array}{c}\text { Independent } \\
\text { Variable }\end{array}$ & $\begin{array}{c}\text { Dependent } \\
\text { Variable }\end{array}$ \\
\hline I & C1 & 0 \\
& (Penonton berat) & (Perilaku sosial) \\
II & C2 & 0 \\
& (Penonton ringan) & (Perilaku sosial) \\
\hline
\end{tabular}

(Sumber : Fraenkel, dkk. 1993, hlm. 321)

Untuk mengumpulkan data hasil penelitian maka instrumen atau alat ukur yang digunakan dalam penelitian ini adalah angket atau kuisioner untuk intensitas menonton sedangkan instrumen untuk perilaku sosial anak dalam bermain sepak bola adalah skala sikap dari Likert.

Pengujian hipotesis menggunakan uji statistik parametrik yaitu uji kesamaan dua rata-rata dengan bantuan Statistic Pockages for Sosial Scence (SPSS) versi 16.

\section{HASIL}

Data perilaku sosial anak penonton berat dan perilaku sosial anak penonton ringan diperoleh melalui penyebaran angket dan skala sikap dari Likert kepada siswa. Skor perilaku sosial anak penonton berat dan perilaku sosial anak penonton ringan sebelumnya didapat dengan cara mengubah data ordinal ke dalam data inteval dengan Method Successive Interval (MSI).

Data hasil penyebaran angket perilaku sosial anak penonton berat dan perilaku sosial anak penonton ringan dideskripsikan dan dianalisis. Deskripsi skor perilaku sosial 
Romi Cendra, Pengaruh Menonton Pertandingan Sepakbola Di Televisi Terhadap Perilaku Sosial Anak Dalam Bermain Sepakbola

anak penonton berat dan perilaku sosial anak penonton ringan disajikan pada tabel dihalaman selanjutnya :

Tabel 2. Perbandingan Perilaku Sosial Penonton Berat dan Perilaku Sosial Penonton Ringan

\begin{tabular}{lcc}
\hline \multicolumn{1}{c}{ Data } & \multicolumn{2}{c}{ Perilaku Sosial } \\
Statistik & $\begin{array}{c}\text { Penonton } \\
\text { Berat }\end{array}$ & $\begin{array}{c}\text { Penonton } \\
\text { Ringan }\end{array}$ \\
\hline $\begin{array}{l}\text { Rata-rata } \\
\text { Standar }\end{array}$ & 146.52 & 135.05 \\
Deviasi & 14.730 & 15.692 \\
\hline
\end{tabular}

Dari hasil uji Independent Sample T-Test didapat nilai sig. (2-tailed) $=0.019(<0.05)$, maka kesimpulannya adalah terdapat perbedaan yang signifikan antara anak yang sering menonton dan anak yang jarang menonton pertandingan sepakbola di televisi terhadap perilaku sosialnya dalam bermain sepakbola.

Dari hasil pengolahan data dan analisis skor yang telah penulis lakukan, diperoleh hasil bahwa anak yang sering menonton atau penonton berat pertandingan sepakbola di televisi memberikan pengaruh yang signifikan terhadap perilaku sosialnya dalam bermain sepakbola.

\section{PEMBAHASAN}

Data analisa dari hasil skala sikap perilaku sosial yang disebarkan kepada responden antara kelompok anak penonton berat/sering dan kelompok anak penonton ringan/jarang, ternyata dari kedua kelompok tersebut rata-rata mempunyai pengaruh positif terhadap perilaku sosialnya dalam bermain sepakbola, namun yang lebih baik dan besar pengaruhnya adalah kelompok anak yang sering menonton atau penonton berat pertandingan sepakbola di televisi, hal ini sesuai dengan teori Kultivasi Garbner, G (dalam Kurniawan, 2013) menjelaskan bahwa televisi memiliki pengaruh yang besar atas sikap dan perilaku penontonnya. Pengaruh tersebut tidak muncul seketika melainkan bersifat kumulatif dan tidak langsung. Lebih jelasnya dapat dikemukakan bahwa pengaruh yang muncul pada diri penonton merupakan tahap lanjut setelah media itu terlebih dahulu mengubah bentuk keyakinan-keyakinan tertentu pada diri mereka melalui berbagai acara yang ditayangkan. West, $R$ \& Turner, L.H. (2008:84) menjelaskan tentang Analisis Kultivasi dari Garbner, $G$ yang mengatakan bahwa dalam masyarakat masa kini, kebanyakan orang mendapatkan informasi mereka dari sumber-sumber yang bermediasi dibandingakan dari kenyataan langsung. Karenanya, sumber-sumber yang bermediasi dapat membentuk kenyataan seseorang.

Oleh karena itu pengaruh pertandingan sepakbola di televisi terhadap perilaku sosial anak dalam bermain sepakbola secara rinci diuraikan sebagai berikut:

Pertama, terdapat pengaruh menonton pertandingan sepakbola di televisi terhadap perilaku sosial anak dalam bermain sepakbola, karena salah satu faktor dari banyak faktor yang mempengaruhi pembentukan perilaku sosial anak dalam bermain sepakbola adalah dengan menonton pertandingan sepakbola di televisi. Sebuah penelitian yang dilakukan oleh $\mathrm{Z}$. Dziubinski, dkk. (2012) dikatakan dikatakan "We are under the influence of a force which we cannot see or realize and which has a massive effect on our behavior and attitudes". (Tanpa disadari kita berada di bawah pengaruh kekuatan yang kita tidak bisa melihat atau menyadari dan yang memiliki besar pengaruhnya terhadap perilaku dan sikap kita).

Beberapa ahli percaya, bahwa media televisi memberikan pengaruh yang besar bagi para penontonnya. Apalagi bagi kelompok anak penonton berat/sering yang menghabiskan banyak waktu menonton pertandingan sepakbola di televisi, tentu ini akan membentuk geografi jiwanya secara bertahap, seperti yang dikatakan Kritikus sosial Novak, M (dalam Vivian, 2008:225) menjelaskan bahwa televisi adalah pembentukan geografi jiwa, televisi membangun struktur ekspektasi jiwa secara bertahap, televisi melakukan itu persis seperti sekolah memberi pelajaran secara bertahap, selama bertahun-tahun, televisi mengajari pikiran yang belum matang dan mengajari mereka cara berpikir.

Terkait dengan hal tersebut bahwa kelompok anak penonton berat/sering menonton pertandingan sepakbola di televisi secara bertahap akan mengajari mereka 
cara berpikir dan melakukan sesuatu sesuai dengan apa yang dilihatnya, apalagi anak yang rutinitas bermain sepakbola mereka tentu menonton pertandingan sepakbola di televisi tidak hanya sebagai hiburan saja tetapi juga dijadikan sebagai pelajaran dan akan membentuk perilaku sosialnya dalam bermain sepakbola, hal ini sesuai dengan teori belajar sosial dari Bandura. Menurut Bandura, kita belajar bukan saja dari pengelaman langsung, tetapi dari peniruan atau peneladanan (modeling). Orang cenderung meniru perilaku yang diamatinya, stimuli menjadi teladan untuk perilakunya. Artinya, kita mampu memiliki keterampilan tertentu, bila terdapat jalinan positif antara stimuli yang kita amati dan karakteristik diri kita.

Hal ini dikuatkan oleh teori Stimulus Organisme Respon dari Skiner seorang ahli psikologi (dalam Notoatmodjo, 2007:133) yaitu merumuskan bahwa perilaku merupakan respons atau reaksi seseorang terhadap stimulus (rangsangan dari luar). Oleh karena itu perilaku terjadi melalui proses adanya stimulus terhadap organisme, dan kemudian organisme tersebut merespon. Jadi secara perlahan-lahan stimulus yang dilihat atau ditonton anak berupa pertandingan sepak bola di televisi seperti sifat pemberani, sifat berkuasa, sifat inisiatif secara sosial, suka bergaul, sifat ramah, simpati, suka bersaing, sifat agresif, sifat kalem, dan suka pamer, kerjasama dalam tim, ketenangan dalam bermain, dan sportifitas akan diresponnya sehingga akan membentuk perilaku sosialnya dalam bermain sepak bola.

Kedua, terdapat perbedaan antara kelompok anak penonton berat dan kelompok anak penonton ringan, karena kelompok anak penonton berat/sering mereka merasa butuh dengan acara pertandingan sepakbola di televisi sehingga anak-anak tahan bergadang dan menunggu acara tersebut sampai dini hari, kalau teori Analisis Kultivasi waktu anak menonton televisi adalah prime-time yaitu sekitar jam 20.00 wib sampai dengan jam 23.00 wib, (West, \& Turner, 2008:86). Artinya pada waktu istirahat, sedangkan menonton pertandingan sepakbola di televisi anakanak tidak tahu waktu istirahatnya yang penting mereka bisa menonton pertandingan sepakbola di televisi, jadi mereka merasa butuh dan senang menonton pertandingan sepakbola di televisi, apalagi bagi anak-anak penonton berat yang juga rutinitas bermain sepakbola tentu ini sangat menambah wawasan dia dalam bermain sepakbola, salah satunya yaitu perilaku sosialnya dalam bermain sepakbola seperti sifat pemberani, sifat berkuasa, sifat inisiatif secara sosial, suka bergaul, sifat ramah, simpati, suka bersaing, sifat agresif, sifat kalem, dan suka pamer, kerjasama dalam tim, ketenangan dalam bermain, dan sportifitas.

Sedangkan pada kelompok anak penonton ringan/jarang mereka tidak merasa butuh dengan menonton pertandingan sepakbola di televisi sehingga mereka menonton pertandingan sepakbola di televisi hanya pada waktu luang atau secara kebetulan ada pertandingan sepakbola di televisi dalam arti kata mereka tidak menyengaja apalagi sampai menunggu dini hari untuk bisa menonton pertandingan sepakbola di televisi. Jadi dapat ditarik kesimpulannya bahwa berdasarkan analisis hasil penelitian dan teori-teori yang mendukung diatas bahwa anak-anak yang sering menonton atau penonton berat pertandingan sepakbola di televisi akan berpengaruh terhadap perilaku sosialnya dalam bermain sepakbola.

\section{KESIMPULAN}

Kesimpulan dari hasil analisis dan pembahasan tentang Pengaruh Pertandingan Sepakbola di Televisi Terhadap Perilaku Sosial Anak Dalam Bermain Sepakbola adalah sebagai berikut: (1) Menonton pertandingan sepakbola di televisi memberikan pengaruh yang signifikan terhadap perilaku sosial anak dalam bermain sepakbola; (2) Terdapat perbedaan yang signifikan antara penonton berat/sering dan penonton ringan/jarang pertandingan sepakbola di televisi terhadap perilaku sosialnya dalam bermain sepakbola.

\section{SARAN}

Atas dasar kesimpulan diatas, peneliti mengajukan beberapa rekomendasi bahwa 
Romi Cendra, Pengaruh Menonton Pertandingan Sepakbola Di Televisi Terhadap Perilaku Sosial Anak Dalam

seorang pendidik dalam bidang sepakbola diharapkan dapat memberikan metode belajar sepakbola untuk anak didiknya, salah satunya yaitu dengan menonton pertandingan sepakbola di televisi dan mengamati perilaku pemainnya baik itu kerjasama dalam timnya, sportifitas, teknik bermain, dan sifat agresivitas para pemainnya untuk dijadikan sebagai wawasan dalam bermain sepakbola.

Penelitian ini hanya menyurvei anak yang sering dan jarang menonton pertandingan sepakbola terhadap perilaku sosial anak dalam bermain sepakbola, tentu ini memiliki bias dalam mengambil keputusan. Oleh karena itu penulis mengharapkan agar peneliti selanjutnya dapat memperhatikan metode yang digunakan sehingga tidak banyak bias dalam mengambil kesimpulan penelitian dan juga menambah vaiabel dependennya dengan motivasi anak dalam bermain sepakbola setelah anak menonton pertandingan sepakbola di televisi. Penulis menduga bahwa metode penelitian eksperimen dan kualitatif akan lebih baik dalam meneliti mengenai pengaruh menonton pertandingan sepakbola di televisi terhadap perilaku sosial anak dalam bermain sepakbola. Khusus untuk perilaku sosial anak menurut peneliti terlalu luas untuk di teliti sehingga peneliti berharap kedepannya kepada peneliti selanjutnya agar membatasi ruang lingkup perilaku sosialnya, contoh hanya berfokus kepada sifat agresivitas anak dalam bermain sepakbola.

\section{DAFTAR RUJUKAN}

Arikunto, S. (2002). Prosedur Penelitian: Suatu Pendekatan Praktik. Edisi kelima. Jakarta: Rineka Cipta.

Budiman, D. (2001). Bahan Ajar M. K Psikologi Anak Dalam Penjas Pgsd. [Online]. Tersedia: http://file.upi.edu /direktori/fpok/jur._pend._olahraga/197 409072001121_didin-

budiman/psikologi_anak_dlm_penjas/p erilaku_sosial.pdf

Bungin, B. (2009). Sosiologi Komunikasi Teori, paradigma, dan Diskursus Teknologi Komunikasi di Masyarakat.
Jakarta: Kencana Prenada Media Group.

Fraenkel, JR, Wallen, NE. (1993). How To Design and Evaluate Research in Education. USA: McGraw Hill, Inc.

Jajat. (2010). Pengaruh Berita Olahraga di Media Massa (Internet) Terhadap Sikap Siswa SMA Pada Aktivitas Jasmani. Tesis UPI.

Hakim, L. (2006). Pengaruh Media Terhadap Kognisi Anak. [Online]. Tersedia: www.psiko-indonesia.blogspot.com

Kerlinger, F.M. (1964). Foundation of Behavioral Research. New York: Holt, Rinehart, \& Winston.

Krech, dkk. (1963). Individual In Society. University of California : McGraw-Hill International Book Company.

Kurniawan, W. (2013). Dampak Buruk Media Massa Terhadap Perilaku Masyarakat. [Online]. Tersedia: http://wahyukurniawan19.blogspot.com/2013/06/dampakburuk-media-massa-terhadap.html

Notoatmodjo, S. (2007a). Promosi Kesehatan dan IImu Perilaku. Jakarta: Rineka Cipta.

Sugiyono. (2005). Metode Penelitian Pendidikan - Pendekatan Kuantitatif, Kualitatif, dan R\&D. Bandung: CV. Alfabeta.

Pedersen, P. M. dkk.(2007). Strategic Sport Communication. Indiana University. Human Kinetics.

Vivian, J. (2008). The Media Of Mass Communicatio; dialihbahasakan dalam Teori Komunikasi Massa, edisi kedelapan. Jakarta: Kencana.

West, R.,\& Turner, L.H. (2008). Introducing Communication Theory: Analysis and Application, $3^{\text {rd }}$ ed. Amarica: Mc Graw Hill.

Z. Dziubinski, K.W. dkk. (2012). Mass Media and Professional Sport. Baltic Journal 
62 GELANGGANG PENDIDIKAN JASMANI INDONESIA, Volume 1, Nomor 1, Tahun 2017 , Halaman 56-62

Of Health and Physical Activity.

Gdansk University of Physical

Education and Sport in Gdansk. 